\title{
Konkurencyjność polskiego przemysłu na tle wybranych państw Europy
}

\begin{abstract}
Competitiveness of Polish industry in comparison to selected European countries: The article presents an assessment of industrial companies in Poland versus companies from selected European countries. It begins with the literature survey in which the authors highlight the specificity and main factors shaping the competitiveness of industry. Both traditional and contemporary determinants of competitiveness are discussed, particularly those associated with spatial integration, effects of concentration on selected growth sectors with a high added value, use of creative skills, quality of institutions and social capital. The authors also analyse the competitiveness of Polish companies with use of some complex measures such as Global Competitiveness Index and the Competitive Industrial Performance Index. The article concludes with indicating the key factors and barriers of competitiveness of Polish industrial companies.
\end{abstract}

Słowa kluczowe: konkurencyjność gospodarki narodowej, konkurencyjność przemysłu, przetwórstwo przemysłowe w Polsce, przemysł w Polsce

Keywords: competitiveness of national economy, competitiveness of industry, manufacturing in Poland, industry in Poland

* Doktor hab. nauk ekonomicznych, profesor na Uniwersytecie Ekonomicznym w Poznaniu, Katedra Polityki Gospodarczej i Samorządowej, Wydział Ekonomii; e-mail: piotr.lis@ue.poznan.pl.

** Doktor nauk ekonomicznych, adiunkt w Katedrze Polityki Gospodarczej i Samorządowej, Wydział Ekonomii, Uniwersytet Ekonomiczny w Poznaniu; e-mail: joanna.mazurkiewicz@ue.poznan.pl.

\section{Wstęp}

Zdolność przedsiębiorstw do konkurowania na rynkach krajowych i zagranicznych jest zjawiskiem niezwykle pożądanym nie tylko dla samych przedsiębiorstw, ale również dla całej gospodarki. Konkurencyjność międzynarodową przedsiębiorstw można rozpatrywać zarówno z perspektywy makroekonomicznej, jak i sektorowej. 
W opracowaniu dokonano próby oceny konkurencyjności przedsiębiorstw przemysłowych $\mathrm{w}$ Polsce $\mathrm{w}$ porównaniu z przedsiębiorstwami z wybranych państw Europy. Opracowanie rozpoczyna się przeglądem literatury, w którym wskazano specyfikę oraz główne czynniki kształtujące poziom konkurencyjności przemysłu. W tej części wskazano zarówno na tradycyjne, jak i współczesne determinanty konkurencyjności, związane z integracją przestrzenną, efektami koncentracji na wybranych sektorach wzrostowych o wysokiej wartości dodanej, korzystaniem z zasobów kreatywnych umiejętności, jakością instytucji i kapitałem społecznym. Następnie autorzy analizowali konkurencyjność polskich przedsiębiorstw z wykorzystaniem współczesnych kompleksowych mierników, w tym Globalnego Indeksu Konkurencyjności (GCI) oraz Indeksu Konkurencyjności Potencjału Przemysłowego (Competitive Industrial Performance Index). Do porównań wybrano kraje Europy sąsiadujące z Polską i istotne w skali gospodarki globalnej, takie jak: Czechy, Niemcy i Rosję. Wskazano na kluczowe czynniki i bariery konkurencyjności polskich przedsiębiorstw przemysłowych.

\section{Przegląd literatury}

\section{Źródła przewagi konkurencyjnej w przemyśle}

Konkurencyjność oznacza zdolność przedsiębiorstw do konkurowania na rynkach krajowych i zagranicznych. Tym samym konkurencyjność polskiego przemysłu oznacza zdolność przedsiębiorstw przemysłowych ulokowanych w Polsce do konkurowania na rynkach międzynarodowych oraz zdolność tych przedsiębiorstw do konkurowania na rynku krajowym $\mathrm{z}$ importem produktów z zagranicy ${ }^{1}$. Taka definicja nie odnosi się do pochodzenia kapitału własnego w przedsiębiorstwach zlokalizowanych w Polsce. Uznaje się, że osiągnięcie właściwego poziomu konkurencyjności polskiego przemysłu umożliwi zrealizowanie głównego celu polityki gospodarczej, jakim jest poprawa standardu i jakości życia obywateli. Odbywa się to w szczególności poprzez tworzenie miejsc pracy i generowanie strumieni dochodów. We współczesnym globalnym świecie warunkiem przełożenia się konkurencyjności krajowego przemysłu na poprawę standardu i jakości życia obywateli jest tworzenie atrakcyjnych miejsc pracy i osiągnięcie możliwie wysokiego poziomu reinwestycji osiągniętych nadwyżek przez przedsiębiorstwa i ich przekształcanie w majątek w kraju lokalizacji przedsiębiorstwa. Oczywiście ten problem staje się ogromnym wyzwaniem dla poszczególnych krajów, a sposoby rozwiązania go są jedną z osi sporu nie tylko ekonomii głównego nurtu.

1 Zob. M. Gorynia, Międzynarodowa konkurencyjność polskiej gospodarki a polityka ekonomiczna, „Ekonomista” 1996, nr 3. 
W prowadzonych rozważaniach należy wyraźnie podkreślić, że na konkurencyjność przemysłu składają się możliwości osiągania, utrzymania lub umocnienia przewagi konkurencyjnej poszczególnych przedsiębiorstw z różnych sektorów przemysłowych. Kształtowana jest ona przez wybór strategii biznesu: konkurencyjną, rozwoju i sieci przedsiębiorstw ${ }^{2}$, potencjał konkurencyjny przedsiębiorstwa oraz relację pozycji konkurencyjnej do atrakcyjności otoczenia ${ }^{3}$.

Konkurencyjność poszczególnych przedsiębiorstw może składać się na konkurencyjność całych sektorów w gospodarce, w przypadku silnych powiązań i zależności pomiędzy samymi przedsiębiorstwami oraz otoczeniem sektorowym i otoczeniem dalszym. Zatem determinanty konkurencyjności przedsiębiorstw przemysłowych mogą być istotnie różne zarówno na poziomie poszczególnych przedsiębiorstw, jak i na poziomie poszczególnych sektorów. Trudno bowiem wskazać gospodarkę osiągającą przewagę konkurencyjną we wszystkich sektorach, natomiast istnieją przykłady państw o istotnych przewagach konkurencyjnych w wybranych sektorach lub grupach sektorów wzajemnie powiązanych w łańcuchu wartości.

W ujęciu teoretycznym wyróżnia się cztery nurty badań nad konkurencyjnością, osadzone w teorii wzrostu gospodarczego, handlu międzynarodowego, analizy cenowo-kosztowej oraz konkurencji ${ }^{4}$. W tej części opracowania uwaga będzie skoncentrowana na dwóch źródłach konkurencyjności: tworzeniu przewagi cenowo-kosztowej oraz podnoszeniu produktywności przedsiębiorstw. W dalszej kolejności omówiona zostanie relacja pomiędzy budowaniem przewag konkurencyjnych przedsiębiorstw a konkurencyjnością sektorów.

Tworzenie przez przedsiębiorstwa przewagi cenowo-kosztowej w handlu międzynarodowym jest możliwe dzięki lokalizacji i dostępowi do specyficznych zasobów. Zgodnie z tym podejściem kraj staje się bardziej konkurencyjny, jeżeli na skutek zmiany relacji koszt-cena lub innych czynników jego zdolność do sprzedaży na rynkach zagranicznych poprawia się̨5. Do najczęściej używanych mierników cenowej konkurencyjności zarówno sektora, jak i gospodarki należą: indeksy cenowe (CPI, PPI), relatywne jednostkowe ceny eksportowe, relatywne

2 O strategii, Harvard Business Review Polska, ICAN Sp. z o.o., Warszawa 2012; Strategia i planowanie biznesu, red. P. Lis, Wydawnictwo Uniwersytetu Ekonomicznego w Poznaniu, Poznań 2014.

3 Zob. odmienne ujęcie w: Luka konkurencyjna na poziomie przedsiębiorstwa a przystapienie Polski do Unii Europejskiej, red. M. Gorynia, Wydawnictwo Akademii Ekonomicznej w Poznaniu, Poznań 2002; M. Dzikowska, M. Gorynia, Teoretyczne aspekty konkurencyjności przedsiębiorstwa - w kierunku koncepcji eklektycznej?, „Gospodarka Narodowa” 2012, nr 4.

${ }^{4}$ A. Wziątek-Kubiak, Konkurencyjność polskiego przemysłu, Bellona, Warszawa, 2003, s. 13.

A. Francis, P. Tharakan, The Competitiveness of European Industry, Routledge, London 1989, s. 20. 
jednostkowe koszty pracy oraz realny efektywny kurs walutowy ${ }^{6}$. Spośród tych czynników najlepszym pojedynczym miernikiem konkurencyjności wydają się być jednostkowe koszty pracy ${ }^{7}$. W sektorach konkurencyjnych płace rosną wolniej niż wydajność pracy ${ }^{8}$, co prowadzi do powstawania bardzo trudnej do kopiowania i przejęcia przewagi.

Takie rozumienie źródeł konkurencyjności przemysłu opiera się na założeniach bliskich logice funkcjonowania przedsiębiorstw nastawionych na zwiększanie sprzedaży dzięki możliwości produkcji po niższych kosztach. Z punktu widzenia całej gospodarki, tj. biorąc pod uwagę budowanie podstaw trwałego wzrostu, jest to strategia krótko- i średniookresowa. Jest ona silnie uzależniona od tempa konwergencji gospodarek, a kraje, które tracą przewagi kosztowe na skutek wzrostu kosztów pracy, mogą być zagrożone utratą równowagi bilansu płatniczego, a tym samym zmiennością przepływów kapitałowych, zmniejszającą szeroko rozumianą stabilność makroekonomiczną gospodarki.

Podejście kosztowe może być także wykorzystywane w ocenie polityki gospodarczej wobec przemysłu. Przykładem tego podejścia w badaniach empirycznych jest przygotowywany przez Bank Światowy indeks w ramach raportu Doing Business, raporty Komisji Europejskiej (Annual Growth Survey) czy opracowania MFW ${ }^{9}$. W opracowaniach tych zwraca się uwagę na koszty regulacji (w tym również system podatkowy), wskazując, że zbyt wysoki poziom kosztów administracyjnych jest głównym czynnikiem ograniczającym konkurencyjność przedsiębiorstw. W pracach Komisji Europejskiej uwagę koncentruje się ponadto na wpływie regulacji na ograniczanie efektywnej konkurencji na rynku.

Drugim źródłem przewagi konkurencyjnej jest wysoki poziom produktywności przedsiębiorstw przemysłowych, który koresponduje zarówno ze wzmocnieniem pozycji gospodarki, jak i podniesieniem poziomu życia ludności ${ }^{10}$. Podniesienie produktywności pozwala na osiąganie lepszych wyników

${ }^{6}$ M. Olczyk, A. Kordalska, Identyfikacja konkurencyjności sektorów przemysłu przetwórczego i ich wptyw na międzynarodową konkurencyjność gospodarki polskiej - analiza panelowa w modelu ECM, seria „Materiały i Studia. Narodowy Bank Polski”, nr 311, Warszawa 2015, s. 12.

Zob. P. Turner, J. Van't Dack's, Measuring International Price and Cost Competitiveness, BIS Economic Paper, 39, Basle 1993; A.G. Turner, S.S. Golub, Towards a System of Unit Labor Cost-Based Competitiveness Indicators for Advanced, Developing and Transition Countries Staff Studies for the World Economic Outlook, IMF Working Paper 97/151, 1997; R. Lewney, Study on the Cost Competitiveness of European Industry in the Globalization Era. Empirical Evidence on the basis of Relative Unit Labour Cost at Sectoral Level, Ecorys 2011.

8 B. Van Ark, E. Stuiwenwol, G. Ympa, Unit Labour Costs, Productivity and International Competitiveness, Groningen Growth and Development Centre, 2005.

9 T. Bayoumi, M. Saito, J. Turunen, Measuring Competitiveness: Trade in Goods or Tasks?, IMF Working Paper 13/100, IMF, Washington 2013.

10 P. Krugman, Competitiveness: A Dangerous Obsession, „Foreign Affairs” 1994, nr 73(2), s. 28-44; idem, The Age of Diminished Expectations, The MIT Press, Cambridge, 1990; M. Por- 
ekonomicznych przedsiębiorstw poprzez wzrost efektywności procesów i wykorzystania zasobów ${ }^{11}$, a nie kosztem utrzymywania niskich kosztów pracy. Z tego puntu widzenia zwiększenie produktywności wpływa na budowanie trwałych podstaw wzrostu gospodarczego ${ }^{12}$ oraz sprzyja zachowaniu równowagi pomiędzy budowaniem silnej pozycji przedsiębiorstw przemysłowych i poprawą sytuacji ekonomicznej ludności (pracowników).

Współcześnie teoretycznych związków między produktywnością a wymianą międzynarodową należy szukać w najnowszych nurtach teorii handlu zagranicznego. W tym ujęciu tylko podmioty o najwyższej produktywności są w stanie wejść na rynek eksportowy i konkurować na nim (hipoteza samoselekcji), a operowanie na rynku zagranicznym prowadzi do ich ekspansji ${ }^{13}$. Zależność między poziomem konkurencyjności a produktywnością przedsiębiorstw wiąże się z ich zdolnością do ponoszenia kosztów stałych związanych z wejściem na rynki zagraniczne, pozyskiwania zasobów pracy, sprostania presji cenowej powstałej w wyniku konkurencji importowej.

Przykładem badań skoncentrowanych na ocenie efektów polityki gospodarczej dla kształtowania produktywności są raporty opracowywane przez Światowe Forum Ekonomiczne (World Economic Forum) w ramach Globalnego Raportu o Konkurencyjności (Global Competitiveness Report) oraz Indeks Konkurencyjności Potencjału Przemysłowego (Competitive Industrial Performance Index) publikowany przez UNIDO (Organizację Narodów Zjednoczonych ds. Rozwoju Przemysłowego). W raportach tych szczególną uwagę zwrócono na badanie czynników stymulujących produktywność i wzrost gospodarczy. Czynniki kosztowe nie stanowią tu przedmiotu oddzielnej analizy, jednak zakłada się, że podążają one endogenicznie za zmianami czynników fundamentalnych.

Podsumowując, należy stwierdzić, że w literaturze wskazuje się na dwa odmienne sposoby określania źródeł konkurencyjności przemysłu. Sposobem, który rodzi mniej kontrowersji w świetle zdolności do budowania trwałych fundamentów rozwoju i podnoszenia zamożności społeczeństwa, jest osiąganie

ter, S. Stern, M. Green, Social Progress Index 2015, Social Progress Imperative, London 2015; The Age of Productivity: Transforming Economies from the Bottom up, Inter-American Development Bank, Washington, April 2010; M. Delgado, C. Ketels, M. Porter, S. Stern S., The Determinants of National Competitiveness, NBER Working Paper 18249, National Bureau of Economic Research, Cambridge 2012.

11 A. Ajitabh, K. Momaya, Competitiveness of Firms: Review of Theory, Frameworks and Models, „Singapore Management Review” 2004, nr 26(1), s. 45-61, s. 58; T. Siudek, A. Zawojska, Competitiveness in The Economic Concepts, Theories And Empirical Research, „Oeconomia" 2014, nr 13(1), s. 91-108.

12 R.E. Hall, C.I. Jones, Why Do Some Countries Produce So Much More Output per Worker than Others?, „Quarterly Journal of Economics” 1999, nr 114(1), s. 83-116.

${ }_{13}$ M. Olczyk, A. Kordalska, Identyfikacja konkurencyjności sektorów przemysłu przetwórczego, op. cit. 
silnej pozycji konkurencyjnej przedsiębiorstw dzięki zwiększaniu ich produktywności. Jest to główna siła długookresowego wzrostu gospodarczego i z tego powodu winna stać się celem polityki gospodarczej. Nie oznacza to jednak odrzucenia koncepcji konkurencyjności kosztowej, a konieczność łączenia obu podejść. Należy w pierwszej kolejności pamiętać, że relacja między kosztami produkcji a produktywnością gospodarek jest kluczowa dla oceny atrakcyjności inwestycyjnej danego regionu. Ponadto relacja między poziomem kosztów pracy a produktywnością jest czynnikiem kształtującym wiele zmiennych makroekonomicznych. Wyższe tempo wzrostu płac niż tempo wzrostu produktywności staje się powodem powstawania nierównowagi makroekonomicznej.

\section{Determinanty konkurencyjności sektorów i gospodarek w powiązaniu z przewagą konkurencyjną przedsiębiorstw}

Prekursorem powiązania przewagi konkurencyjnej przedsiębiorstw z atrakcyjnością sektorów i konkurencyjnością gospodarek był Michael Porter ${ }^{14}$. Podjął on próbę odpowiedzi na pytanie, dlaczego określone przedsiębiorstwa zlokalizowane w danych krajach są zdolne do trwałych innowacji, pokonywania zagrożeń i wykorzystywania szans, ciągłego doskonalenia, poszukiwania unikatowych źródeł przewag konkurencyjnych? Odpowiedzią jest kompleksowy zestaw cech, determinant konkurencyjności krajów, zwany „diamentem Portera”. Ekonomista zalicza do niego następujące atrybuty: a) wyposażenie kraju w czynniki wytwórcze, b) czynniki popytowe, c) kształtowanie się odpowiedniego układu sektorowego w danym kraju, d) warunki tworzenia, organizacji i zarządzania przedsiębiorstwami w danym kraju. Należy przy tym zaznaczyć, że grupy czynników oddziałują na konkurencyjność kraju kompleksowo, a nie indywidualnie.

W pierwszej grupie konkurencyjności gospodarki zostało podkreślone znaczenie wyposażenia w czynniki wytwórcze. Obejmuje ono zasoby ludzkie, zasoby rzeczowe, zasoby wiedzy, zasoby kapitału i infrastrukturę. Podkreśla się, że w tej przestrzeni ekonomicznej szczególną rolę może pełnić transfer wiedzy, zaawansowana technologia, dyfuzja innowacji, postęp technologiczny oraz technologie informatyczne ${ }^{15}$. Proces globalizacji przyspieszył przesunięcie zasobów kapitału i przede wszystkim wysoko wykwalifikowanej kadry pomiędzy krajami.

W drugiej grupie czynników konkurencyjności gospodarki M. Porter ${ }^{16}$ wymienił znaczenie struktury i charakteru popytu krajowego. W sytuacji, gdy krajowi nabywcy stają się bardziej wymagający, informują szybko i z dużą presją o własnych potrzebach, to przedsiębiorstwa muszą szybciej udoskonalać i unowocześniać swoją ofertę produktową, co prowadzi do zwiększenia konkuren-

${ }_{14}$ M. Porter, The Competitive Advantage of Nations, Macmillan Press, 1990.

15 Zob. K. Malaga, O niektórych dylematach teorii wzrostu gospodarczego i ekonomii, 2012, http://www.pte.pl/pliki/2/12/K.\%20Malaga.pdf [dostęp: 15 czerwca 2018 r.].

${ }^{16}$ M. Porter, The Competitive Advantage of Nations, op. cit. 
cyjności sektora i całej gospodarki. Ponadto ważny jest udział poszczególnych segmentów w popycie ogółem, poziom wymagań klientów i zdolność przedsiębiorstw do przewidywania zmieniających się potrzeb klientów z różnych krajów ${ }^{17}$.

We współczesnych teoriach wymiany handlowej popyt krajowy stał się podstawową determinantą importu, a wielkość popytu zagranicznego determinuje eksport danego $\mathrm{kraju}^{18}$. Na silnie zglobalizowanych i często zintegrowanych rynkach, pozbawionych barier, i wśród partnerów o podobnej strukturze popytu, krajowi konsumenci wykazują zamiłowanie do różnorodności (model Dixita-Stiglitza - „Love of variety”), tj. do bliskich substytutów w konsumpcji, importowanych z zagranicy ${ }^{19}$. Według Magdaleny Olczyk i Aleksandry Kordalskiej ${ }^{20}$ we współczesnej gospodarce obserwowana jest rosnąca rola globalnych łańcuchów wartości w handlu międzynarodowym, a także wzrost tzw. handlu zadaniami. Oba zjawiska powodują coraz silniejszą współzależność gospodarek na linii popyt krajowy - popyt zagraniczny a import-eksport ${ }^{21}$.

Trzecią grupą czynników konkurencyjności gospodarki jest kształtowanie się odpowiedniego układu sektorowego, w szczególności konkurencyjnego sektora dostawców i sektorów pokrewnych. W wielu przypadkach, chociaż nie zawsze, sprawne funkcjonowanie sektora dostawców umożliwia szybszy, pewny, a czasem preferencyjny dostęp do zasobów rzeczowych niezbędnych w procesie produkcyjnym. Z kolei istnienie grup przedsiębiorstw i powiązanych $\mathrm{z}$ nimi instytucji zajmujących się określoną dziedziną, połączonych podobieństwami i wzajemnie się uzupełniających (klastrów), powoduje efekt synergiczny, polegający przede wszystkim na dyfuzji know-how oraz rotacji kadr, zwiększenie produktywności poprzez skupienie zasobów, otwartości na innowacje i zdolności do przyciągania nowych zasobów i przedsiębiorstw ${ }^{22}$.

W czwartej grupie czynników konkurencyjności gospodarki znajdują się warunki tworzenia przedsiębiorstw, ich organizacji i zarządzania nimi. Należy podkreślić, że funkcjonują odmienne style zarządzania, czasami kojarzone z poszczególnymi krajami, w inny sposób tworzy się kulturę organizacyjną przedsiębiorstwa w zależności od miejsca jego lokalizacji, ale również inna jest charakte-

${ }^{17}$ M. Gorynia, Międzynarodowa konkurencyjność polskiej gospodarki a polityka ekonomiczna, op. cit., s. 346.

${ }_{18}$ M. Olczyk, A. Kordalska, Identyfikacja konkurencyjności sektorów przemysłu przetwórczego, op. cit., s. 10.

19 A. Dixit, J. Stiglitz, Monopolistic Competition and Optimum Product Diversity, „American Economic Review" 1977, nr 67(3).

${ }_{20}$ M. Olczyk, A. Kordalska, Identyfikacja konkurencyjności sektorów przemysłu przetwórczego, op. cit., s. 10.

${ }^{21}$ Zob. R. Lanz, S. Miroudot, H.K. Nordås, Trade in Tasks, „OECD Trade Policy Working Papers" 2011, nr 117.

22 Zob. J. Kaźmierski, Klastry jako źródło efektów synergetycznych i instrument zarządzania regionalnego, „Acta Universitatis Lodziensis. Folia Oeconomica” 2011, nr 251. 
rystyka konkurentów w zależności od kraju. Rozwój technologii informatycznych i szybki dostęp do informacji spowodowały gwałtowną zmianę struktur organizacyjnych przedsiębiorstw, które przechodzą: od patrzenia do środka na postrzeganie otoczenia, od stałości do zmienności, od biurokracji do adhokracji, czyli określania organizacji charakteryzującej się tymczasowością i zredukowaną do minimum strukturą formalną, od przetwarzania rzeczy do przetwarzania informacji, od wykorzystania pracowników do rozwijania ich kreatywności, od walki z konkurencją do współpracy, od prostoty do złożoności, od zamykania się do otwartości, od nastawienia na zagrożenia do nastawienia się na szanse ${ }^{23}$.

Do powyższych determinant konkurencyjności kraju należy dodać politykę gospodarczą państwa (rządu i samorządów lokalnych) oraz wsparcie zdolności przedsiębiorstw do wykorzystania szans i unikania zagrożeń pojawiających się $\mathrm{w}$ otoczeniu ${ }^{24}$.

\section{Pomiar konkurencyjności przemysłu}

Przejawem i zarazem miernikiem międzynarodowej konkurencyjności całej gospodarki jest dodatnie saldo wymiany handlowej ${ }^{25}$. W tym miejscu można zestawić przykład gospodarki Niemiec, o długookresowym dodatnim saldzie wymiany handlowej, z gospodarką Stanów Zjednoczonych, o wyraźnie ujemnym saldzie wymiany handlowej. Tym samym można dostrzec, że nadwyżka lub deficyt handlowy nie jest uniwersalną miarą konkurencyjności gospodarek ${ }^{26}$.

Kompleksowym miernikiem konkurencyjności gospodarki jest Globalny Indeks Konkurencyjności publikowany w ramach Globalnego Raportu Konkurencyjności przez Światowe Forum Ekonomiczne. Definiuje ono konkurencyjność jako zestaw instytucji, polityk i czynników, które determinują poziom wydajności gospodarki, a w konsekwencji poziom rozwoju, jaki może osiągnąć dana gospodarka. Pomiar konkurencyjności został oparty na czterech grupach

${ }^{23}$ A. Kałowski, J. Wysocki, Zmiany w organizacji współczesnych przedsiębiorstw, „ZS WSH Zarządzanie" 2014, nr 1.

${ }^{24}$ Zob. M. Gorynia, Międzynarodowa konkurencyjność polskiej gospodarki a polityka ekonomiczna, op. cit.

${ }^{25}$ M. Olczyk, A. Kordalska, Identyfikacja konkurencyjności sektorów przemystu przetwórczego, op. cit.; zob. A. Deardorff, The General Validity of the Law of International Competitiveness, „Journal of Political Economy” 1980, nr 88(5); Ch. Greenhalgh, P. Taylor, Innovation and Export Values and Prices, „CEPR Discussion Papers” 1990, nr 487; Ch. Greenhalgh, P. Taylor, R. Wilson, Innovation and Export Values and Process - a Disaggregated Study, „Oxford Economic Papers" 1994, nr 46(1); L. Soete, A General Test of Technological Gap Trade Theory, „Weltwirtschaftiches Archiv” 1981, nr 117(4).

${ }^{26}$ Zob. A.J. Lenz, Beyond Blue Economic Horizons: U. Trade Performance and International Competitiveness in the 1990s, Praeger, New York 1991; R. Parry, U.S. Trade Deficit and International Competitiveness, „Business Economics” 1994, nr 29(1); J. Blecker, The Trade Deficit Trap: How It Got So Big, Why It Persists, and What to Do About It, Working Paper No. 284, Economic Policy Institute, Washington 2009. 
atrybutów składających się z 12 kryteriów, takich jak: instytucje, infrastruktura, potencjał technologiczny, otoczenie makro, zdrowie, edukacja, efektywność rynku produktów, efektywność rynku pracy, rozwój rynku finansowego, wielkość rynku oraz przedsiębiorczość i potencjał innowacyjny.

Dla oceny konkurencyjności potencjału przemysłowego poszczególnych gospodarek powstał Indeks Konkurencyjności Potencjału Przemysłowego publikowany przez UNIDO. W raporcie UNIDO zastosowano trzy główne wymiary konkurencyjności i sześć głównych wskaźników (w tym dwa złożone), które koncentrują się na przetwórstwie przemysłowym (manufacturing) jako części przemysłu (industry). Takie ujęcie wydaje się jednak zasadne, gdyż uwzględniono tę część przemysłu, która w największym stopniu podlega wymianie międzynarodowej. Wyłączono zatem $\mathrm{z}$ oceny górnictwo i wydobywanie, wytwarzanie i zaopatrywanie w energię elektryczną, gaz, parę wodną, gorącą wodę, dostawę wody, gospodarowanie ściekami i odpadami, rekultywację. Tym samym wykluczono z analizy w zasadzie tę część przemysłu, która ze swej istoty nie podlega wymianie międzynarodowej i w tym sensie trudno przypisać jej konkurencyjność międzynarodową lub, jak w przypadku górnictwa, podlega specyficznym mechanizmom konkurowania na rynkach międzynarodowych.

Pierwszy wymiar tworzy zdolność do produkowania i eksportowania produktów przetwórstwa przemysłowego, na który składa się (1) wartość dodana w przetwórstwie przemysłowym per capita, oraz (2) wartość eksportu przetwórstwa przemysłowego per capita. Drugi wymiar stanowi technologiczne zaawansowanie produktów. W skład tego wymiaru wchodzi złożony wskaźnik intensywności uprzemysłowienia, stanowiący średnią arytmetyczną dwóch wskaźników: (3) udziału wartości dodanej w przetwórstwie przemysłowym sektora średniej i wysokiej technologii w całkowitej wartości dodanej w przetwórstwie przemysłowym oraz (4) udziału wartości dodanej w przetwórstwie przemysłowym w PKB. Ponadto drugi wymiar stanowi złożony wskaźnik jakości eksportu, stanowiący średnią arytmetyczną dwóch mierników: (5a) udziału eksportu przetwórstwa przemysłowego średniej i wysokiej technologii w całkowitym eksporcie w przetwórstwie przemysłowym oraz (5b) udziału eksportu przetwórstwa przemysłowego w całkowitym eksporcie. Trzeci wymiar stanowi wpływ produkcji danego kraju na gospodarkę światową. Wymiar ten składa się z dwóch mierników, a mianowicie: (6a) wpływ danego kraju na wartość dodaną w światowym przetwórstwie przemysłowym, (6b) udział danego kraju w światowym eksporcie przetwórstwa przemysłowego. Indeks Konkurencyjności Potencjału Przemysłowego (wskaźnik syntetyczny), decydujący o pozycji danego kraju w rankingu, powstaje w wyniku geometrycznej agregacji sześciu nieważonych głównych wskaźników ${ }^{27}$.

27 United Nations Industrial Development Organization, Industrial Development Report 2018. Demand for Manufacturing: Driving Inclusive and Sustainable Industrial Development, UNIDO, Vienna 2017, s. 179. 
Ocena pierwszego i drugiego wymiaru indeksu i wskaźników w nich zawartych jest generalnie pozytywna. Wykorzystane wskaźniki są miarami złożonymi, zawierają dane statystyczne przetworzone dla potrzeb indeksu, posiadają punkt odniesienia, są dostosowane do wielkości gospodarek (na przykład częste wykorzystanie wartości per capita). Wskaźniki zawarte w trzecim wymiarze tracą zaletę dostosowania do wielkości gospodarek. Duże gospodarki będę uzyskiwać wyższe wyniki w udziale w światowym eksporcie i w tym obszarze należy być ostrożnym z formułowaniem ocen. Swoistą wadą Indeksu Konkurencyjności Potencjału Przemysłowego jest również brak ciągłości szacunków i niesystematyczne publikacje wyników badań $(2010,2015)$. Wymiary tworzą kompleksowy obraz konkurencyjności przetwórstwa przemysłowego, chociaż dwa ostatnie mierniki, 6a i 6b, powinny zostać lepiej zdefiniowane.

\section{Konkurencyjność polskiej gospodarki i przemysłu}

Polska gospodarka wytworzyła w 2017 r. 0,88\% światowego produktu brutto. W strukturze produkcji przemysłowej sprzedanej w Polsce udział przetwórstwa przemysłowego wynosił ponad $87 \%$ w pierwszym kwartale 2018 r., przy $8 \%$ udziale wytwarzania i zaopatrywania w energię elektryczną, gaz, parę wodną i gorącą wodę, 3\% udziale górnictwa i wydobywania, 2\% udziale dostawy wody, gospodarowania ściekami i odpadami, rekultywacji. Z perspektywy międzynarodowej konkurencyjności przemysłu najważniejszym parametrem będzie przetwórstwo przemysłowe podlegające wymianie handlowej.

Biorąc pod uwagę saldo wymiany handlowej w kategoriach grup produktowych, należy podkreślić, że nadwyżki eksportu nad importem generowała w Polsce przede wszystkim żywność, napoje i tytoń oraz pozostałe wyroby przemysłowe, do których zalicza się m.in. papier, tekstylia, meble, buty (sekcja 6 i 8 klasyfikacji SITC). W pozostałych grupach produktowych występowały deficyty w wymianie handlowej, w szczególności w surowcach i paliwach mineralnych, chemikaliach i produktach pokrewnych oraz maszynach, urządzeniach i sprzęcie transportowym (wykres 1 i tabela 1). Wydaje się zasadny wniosek, że polskie przedsiębiorstwa generują nadwyżki handlowe w wymianie produktów stosunkowo mało zaawansowanych technologicznie, opartych na zasobie ziemi lub pracy.

W części teoretycznej niniejszego opracowania zwrócono szczególną uwagę na czynnik płacowy w powiązaniu z produktywnością pracy. Związek tych dwóch elementów ukazuje wskaźnik płacy skorygowanej produktywnością (the wage-adjusted labour productivity ratio) oszacowany przez Eurostat w 2018 r. dla danych do 2015 r. Definiuje on wartość dodaną w przemyśle podzieloną przez średnie koszty pracy niezależnie od sposobu zatrudnienia, wyrażony w procentach. W tabeli 2 ukazano wskaźnik płacy skorygowanej produktywnością w przetwórstwie przemysłowym w wybranych krajach UE oraz jego składowe 


\section{Wykres 1. Saldo obrotów towarowych ogółem wybranych krajów Unii Europejskiej w latach 2004-2017 \\ (w mln euro)}

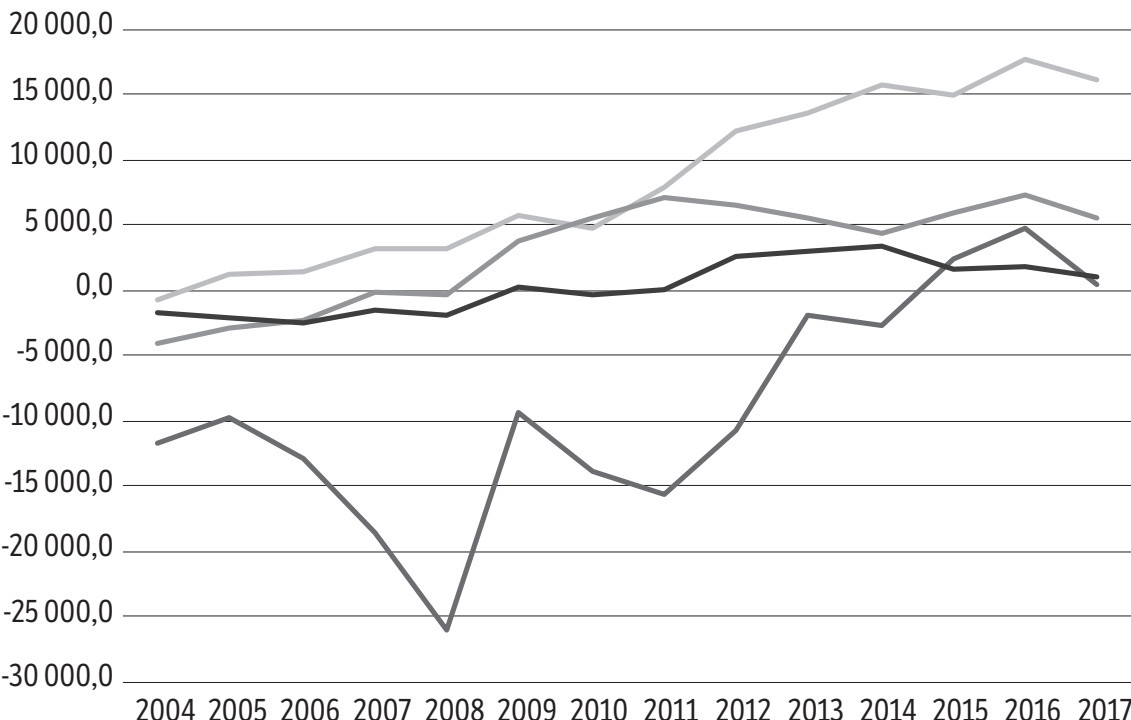

- Czechy — Węgry — Polska - Słowacja

Źródło: Eurostat (ext_It_intratrd) [dostęp: 15 czerwca 2018 r.].

w postaci wartości dodanej brutto na zatrudnionego w tysiącach euro oraz koszty osobowe na zatrudnionego w tysiącach euro. Najniższe średnie koszty osobowe w analizowanej grupie krajów były w Polsce, podobnie jak i najniższa wartość dodana brutto w przetwórstwie przemysłowym na zatrudnionego. Wskaźnik płacy skorygowanej produktywnością w Polsce wynosił 192,1 w 2015 r. Oznacza to, że za 100 euro kosztów pracy wytworzono 192,1 euro wartości dodanej w przetwórstwie przemysłowym. Z jednej strony można zinterpretować powyższą relację, że istnieje rezerwa na wzrost wynagrodzeń. $Z$ drugiej przewaga konkurencyjna przedsiębiorstw przemysłowych w Polsce była zdeterminowana wyraźnie niższymi kosztami pracy. Generowaliśmy prawie trzykrotnie niższą wartość dodaną w przetwórstwie przemysłowym niż Niemcy.

Wartość dodana produkcji przemysłowej stanowiła 18,5\% PKB w 2017 r. (przy 16,6\% w 2004 r.), czyli poniżej wartości dla Czech (24,2\%), Niemiec (20,7\%), Węgier (19,9\%) czy Słowacji (20,1\%). Przyrost produkcji przemysłowej w Polsce w latach 2004-2017 był jednak bardzo dynamiczny, co widać na wykresie 2, powyżej dynamiki dla Węgier i Czech, chociaż znacznie poniżej potencjału gospodarczego kraju, biorąc pod uwagę osiągane poziomy.

Na podstawie wyników Globalnego Indeksu Konkurencyjności 2017-2018 dla 137 gospodarek do pierwszej dziesiątki najbardziej konkurencyjnych gospo- 
Tabela 1. Saldo obrotów towarowych według nomenklatury SITC w wybranych krajach Unii Europejskiej

(w mln euro)

\begin{tabular}{|c|c|c|c|c|c|c|}
\hline \multicolumn{2}{|r|}{ Wyszczególnienie } & Czechy & Niemcy & Węgry & Polska & Słowacja \\
\hline \multirow{6}{*}{ ঠ্ণ } & Ogółem, w tym & $-788,6$ & 156077,9 & $-3996,8$ & $-11777,1$ & $-1701,8$ \\
\hline & Surowce niejadalne z wyjątkiem paliw & $-323,4$ & $-8795,8$ & 61,2 & $-1116,2$ & $-251,0$ \\
\hline & $\begin{array}{l}\text { Paliwa mineralne, smary i produkty } \\
\text { pochodne }\end{array}$ & $-1643,2$ & $-38309,8$ & $-1722,2$ & $-3335,1$ & $-1386,2$ \\
\hline & Chemikalia i produkty pokrewne & $-2960,1$ & 30370,1 & $-1288,4$ & $-6310,4$ & $-1151,7$ \\
\hline & Maszyny, urządzenia i sprzęt transportowy & 4222,9 & 154706,6 & 2099,5 & $-4474,3$ & 665,9 \\
\hline & Pozostałe wyroby przemysłowe & 1193,8 & 27063,5 & $-3022,4$ & 2268,6 & 902,4 \\
\hline \multirow{6}{*}{ ¿ิ } & Ogółem, w tym & 3158,6 & 194258,5 & $-120,7$ & $-18652,5$ & $-1533,0$ \\
\hline & Surowce niejadalne z wyjątkiem paliw & 143,7 & $-12881,3$ & 34,7 & $-1412,0$ & $-336,6$ \\
\hline & $\begin{array}{l}\text { Paliwa mineralne, smary i produkty } \\
\text { pochodne }\end{array}$ & $-4463,4$ & $-60148,0$ & $-4659,4$ & $-8105,8$ & $-2740,4$ \\
\hline & Chemikalia i produkty pokrewne & $-3916,4$ & 36064,7 & $-868,4$ & $-8191,6$ & $-1779,5$ \\
\hline & Maszyny, urządzenia i sprzęt transportowy & 11337,5 & 196079,2 & 6558,6 & $-1263,5$ & 3064,2 \\
\hline & Pozostałe wyroby przemysłowe & 1025,1 & 32465,1 & $-3233,7$ & 993,0 & 720,8 \\
\hline \multirow{6}{*}{ 엄 } & Ogółem, w tym & 4774,5 & 153963,8 & 5510,0 & $-13823,1$ & $-273,5$ \\
\hline & Surowce niejadalne $z$ wyjątkiem paliw & 474,4 & $-14701,9$ & 309,4 & $-1487,5$ & $-537,5$ \\
\hline & $\begin{array}{l}\text { Paliwa mineralne, smary i produkty } \\
\text { pochodne }\end{array}$ & $-5442,9$ & $-73584,9$ & $-5055,7$ & $-9449,5$ & $-3843,1$ \\
\hline & Chemikalia i produkty pokrewne & $-3771,0$ & 44432,2 & $-634,3$ & $-8839,2$ & $-1862,6$ \\
\hline & Maszyny, urządzenia i sprzęt transportowy & 13232,4 & 168904,0 & 9685,7 & 3458,3 & 5455,4 \\
\hline & Pozostałe wyroby przemysłowe & 1486,7 & 28478,5 & $-453,4$ & 2182,7 & 1588,6 \\
\hline \multirow{6}{*}{$\stackrel{m}{\stackrel{m}{N}}$} & Ogółem, w tym & 13564,1 & 198655,3 & 5565,7 & $-1975,0$ & 3023,2 \\
\hline & Surowce niejadalne z wyjątkiem paliw & 355,0 & $-16952,2$ & 678,3 & $-1530,7$ & $-398,3$ \\
\hline & $\begin{array}{l}\text { Paliwa mineralne, smary i produkty } \\
\text { pochodne }\end{array}$ & $-7511,8$ & $-96387,5$ & $-6431,6$ & $-10677,3$ & $-4368,9$ \\
\hline & Chemikalia i produkty pokrewne & $-4832,4$ & 56502,6 & 197,2 & $-8187,2$ & $-2223,5$ \\
\hline & Maszyny, urządzenia i sprzęt transportowy & 21324,7 & 224244,2 & 8044,5 & 5636,0 & 10531,8 \\
\hline & Pozostałe wyroby przemysłowe & 4870,8 & 29497,2 & 282,1 & 9824,7 & 528,4 \\
\hline \multirow{6}{*}{$\stackrel{\text { ำ }}{\stackrel{\circ}{\sim}}$} & Ogółem, w tym & 14882,7 & 248195,7 & 5898,8 & 2350,6 & 1678,3 \\
\hline & Surowce niejadalne $z$ wyjątkiem paliw & 483,9 & $-15606,3$ & 299,9 & $-1621,7$ & $-385,2$ \\
\hline & $\begin{array}{l}\text { Paliwa mineralne, smary i produkty } \\
\text { pochodne }\end{array}$ & $-4095,0$ & $-59733,8$ & $-4610,4$ & $-6952,7$ & $-2774,3$ \\
\hline & Chemikalia i produkty pokrewne & $-5697,3$ & 59083,2 & $-128,9$ & $-8981,9$ & $-2567,3$ \\
\hline & Maszyny, urządzenia i sprzęt transportowy & 20655,7 & 244369,7 & 8874,4 & 4310,2 & 8838,8 \\
\hline & Pozostałe wyroby przemysłowe & 3864,5 & 18081,2 & $-979,3$ & 9703,7 & $-294,6$ \\
\hline \multirow{6}{*}{ స్ } & Ogółem, w tym & 16090,0 & 248781,7 & 5565,4 & 439,5 & 1054,0 \\
\hline & Surowce niejadalne $z$ wyjątkiem paliw & 560,6 & $-17119,9$ & 244,4 & $-2530,0$ & $-672,3$ \\
\hline & $\begin{array}{l}\text { Paliwa mineralne, smary i produkty } \\
\text { pochodne }\end{array}$ & $-4931,4$ & $-58362,8$ & $-4677,9$ & $-9398,2$ & $-2952,6$ \\
\hline & Chemikalia i produkty pokrewne & $-6093,2$ & 60995,5 & 375,5 & $-10339,3$ & $-3158,1$ \\
\hline & Maszyny, urządzenia i sprzęt transportowy & 24226,0 & 247122,7 & 8803,4 & 5169,7 & 9241,7 \\
\hline & Pozostałe wyroby przemysłowe & 2994,0 & 23025,6 & $-1541,7$ & 10732,6 & 146,9 \\
\hline
\end{tabular}

Źródło: jak pod wykresem 1. 
Tabela 2. Wskaźnik płacy skorygowanej produktywnością w wybranych krajach Unii Europejskiej w 2015 r.

\begin{tabular}{|l|c|c|c|}
\hline Wyszczególnienie & $\begin{array}{c}\text { Wartość dodana brutto } \\
\text { w przetwórstwie } \\
\text { przemysłowym na } \\
\text { zatrudnionego (w tys. euro) }\end{array}$ & $\begin{array}{c}\text { Średnie koszty } \\
\text { osobowe w przetwórstwie } \\
\text { przemysłowym } \\
\text { (w tys. euro) }\end{array}$ & $\begin{array}{c}\text { Wskaźnik płacy } \\
\text { skorygowanej } \\
\text { produktywnością (w \%) }\end{array}$ \\
\hline Czechy & 28,3 & 16,1 & 175,6 \\
\hline Niemcy & 73,6 & 55,1 & 133,6 \\
\hline Polska & 24,8 & 12,9 & 192,1 \\
\hline Słowacja & 27,3 & 16,2 & 167,9 \\
\hline Węgry & 30,6 & 13,7 & 223,8 \\
\hline
\end{tabular}

Źródło: Eurostat (sbs_na_ind_r2) [dostęp: 15 czerwca 2018 r.].

Wykres 2. Wartość dodana w przetwórstwie przemysłowym w Polsce w porównaniu z Czechami i Węgrami w latach 2004-2017, indeks łańcuchowy 2010=100 (w mln euro)

90000

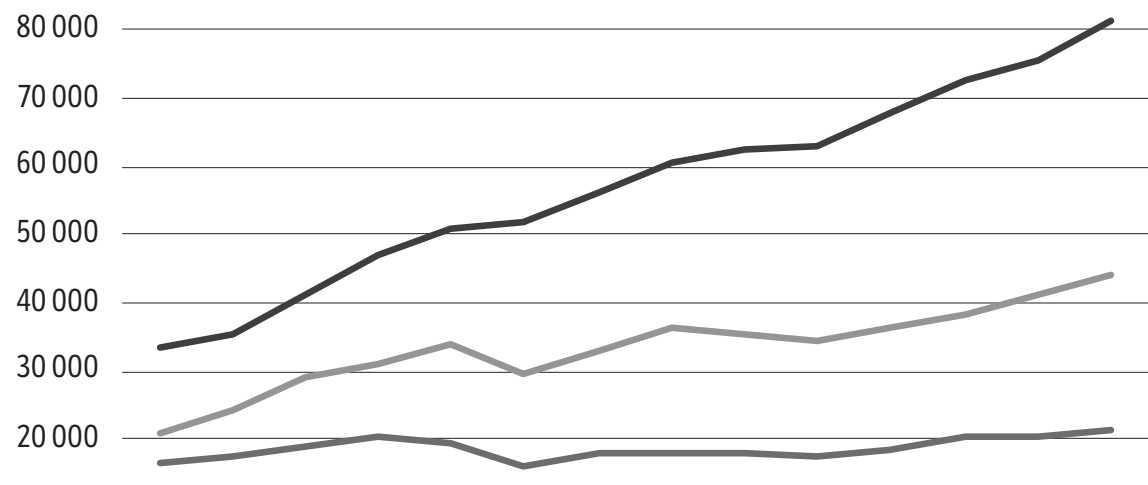

10000

0

20042005200620072008200920102011201220132014201520162017

Czechy — Węgry Polska

Źródło: Eurostat (nama_10_a10) [dostęp: 15 czerwca 2018 r.].

darek świata weszły takie kraje, jak: Szwajcaria (1 miejsce), Stany Zjednoczone (2), Singapur (3), Holandia (4), Niemcy (5), Specjalny Region Administracyjny Hongkong (6), Szwecja (7), Wielka Brytania (8), Japonia (9) i Finlandia (10). Polska gospodarka zajęła dopiero 39. miejsce, między innymi za Estonią (29), Czechami (31) i Rosją (38).

Na wykresie 3 dokonano porównania Polski z Czechami, Niemcami i Rosją w zakresie poszczególnych kryteriów Globalnego Indeksu Konkurencyjności. Wśród ocenianych kryteriów szczególnie niekorzystnie kształtuje się w Polsce 


\section{Wykres 3. Globalny Indeks Konkurencyjności 2017 dla Czech, Niemiec, Rosji i Polski}

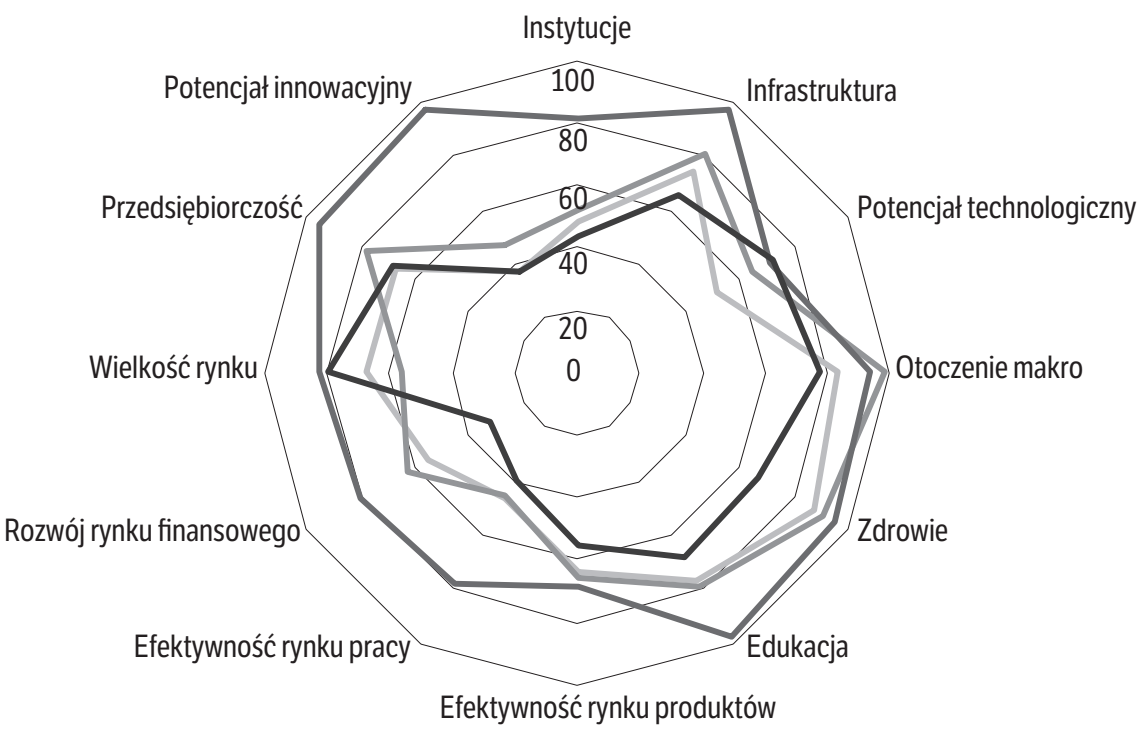

- Polska _ Czechy — Niemcy _Rosja

Źródło: World Economic Forum, Geneva.

potencjał innowacyjny i przedsiębiorczość oraz jakość instytucji i potencjał technologiczny. W obszarze innowacji spora część gospodarek światowych znajduje się znacznie przed Polską, a dynamika zmian nie pozwoli nam nadrobić powstających zaległości. Warto podkreślić, że najważniejsze gospodarki krajów rozwijających się, takie jak Chiny, Indie i Indonezja, stają się centrami dla innowacji, doganiając tym samym gospodarki rozwinięte. Przedsiębiorstwa w tych krajach bardzo szybko adaptują nowe technologie, co jest podstawowym warunkiem rozprzestrzeniania się korzyści ekonomicznych i społecznych związanych z innowacjami. W porównaniu z krajami regionu Europy i Ameryki Północnej Polska znajduje się w większości tych kryteriów poniżej średniej dla tej grupy krajów, z wyjątkiem kryterium wielkość rynku, dla którego ocena jest wyższa niż średnia dla regionu, oraz kryterium zdrowia i otoczenia makro, dla których ocena jest na poziomie średniej regionu. Te niekorzystne oceny w badaniach porównawczych uwypuklają jedynie rzeczywiste problemy i zaległości w tworzeniu konkurencyjności polskich przedsiębiorstw przemysłowych.

W badaniu ankietowym (204 ankiety w Polsce w 2017 r.) przedsiębiorcy wskazali najbardziej problemowe obszary dla działalności gospodarczejej ${ }^{28}$.

28 P. Boguszewski, D. Mirowska-Wierzbicka, Globalny raport konkurencyjności 2017-18 Światowego Forum Gospodarczego, Narodowy Bank Polski, Warszawa 2017. 
W Polsce wyraźnie dominowały aspekty podatkowe i fiskalne, przy barierach prawa pracy i niestabilnej polityce gospodarczej (wykres 4). Firmy w zasadzie nie dostrzegały problemu niskiej innowacyjności, która z kolei na tle świata staje się problemem kluczowym. Taka dysproporcja wyników pomiędzy porównaniami międzynarodowymi a oceną polskich przedsiębiorców może wskazywać, że budowanie przewagi konkurencyjnej w Polsce wciąż w znacznym stopniu opiera się na tworzeniu przewagi kosztowej, a nie na próbie wyróżniania się czy koncentracji na wyróżnianiu. Oznacza to również, że przedsiębiorstwa mają na tyle duży rynek krajowy, iż nie muszą i nie chcą specjalnie budować międzynarodowej przewagi konkurencyjnej.

\section{Wykres 4. Najbardziej problemowe obszary dla działalności gospodarczej w Polsce}

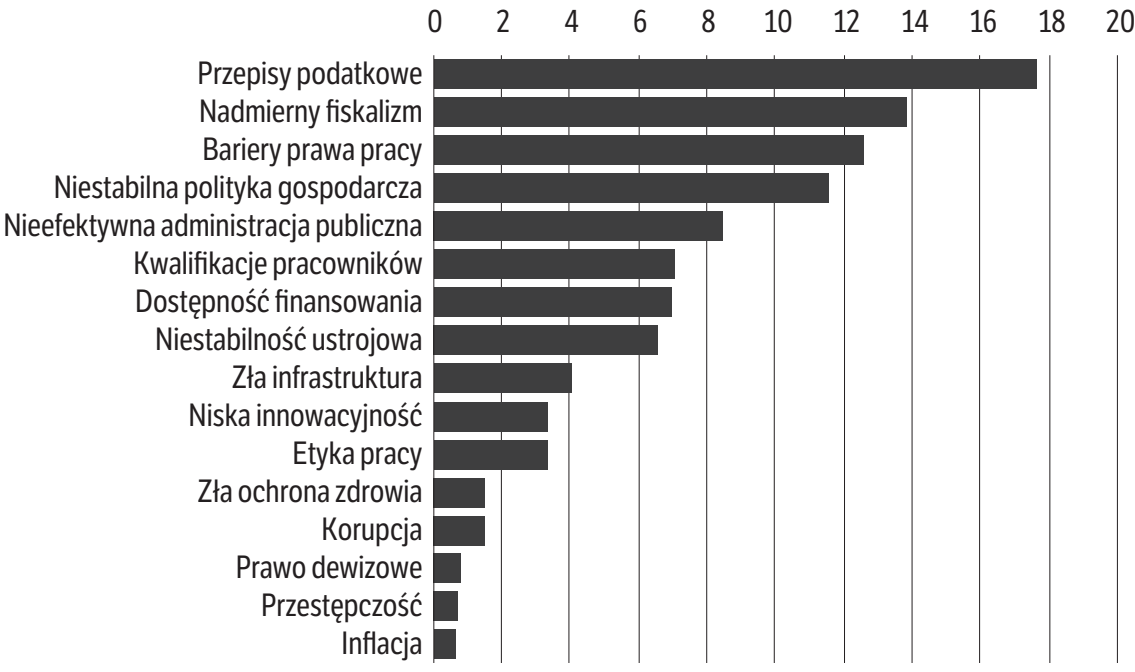

Źródło: World Economic Forum, Executive Opinion Survey 2017.

Na podstawie Indeksu Konkurencyjności Potencjału Przemysłowego UNIDO opracowanego w 2018 r. dla 148 krajów, według stanu gospodarek na koniec 2015 r., do pierwszej dziesiątki najbardziej konkurencyjnego przemysłu weszły takie kraje, jak: Niemcy (1 miejsce), Japonia (2), Chiny (3), Stany Zjednoczone (4), Korea Południowa (5), Szwajcaria (6), Belgia (7), Holandia (8), Singapur (9) i Włochy (10). Polski przemysł zajął 23. miejsce za Czechami (19), ale przed Rosją (32) czy Estonią (50). W stosunku do 2010 r. nastąpiło niewielkie przesunięcie lokaty z 26 miejsca.

W tabeli 3 i na wykresie 5 przedstawiono porównanie Polski z Czechami, Niemcami i Rosją w zakresie wskaźników Indeksu Konkurencyjności Potencjału Przemysłowego. W wymiarze zdolności do produkowania i eksportowania produktów przetwórstwa przemysłowego Polska bardzo mocno odstaje nie tylko 


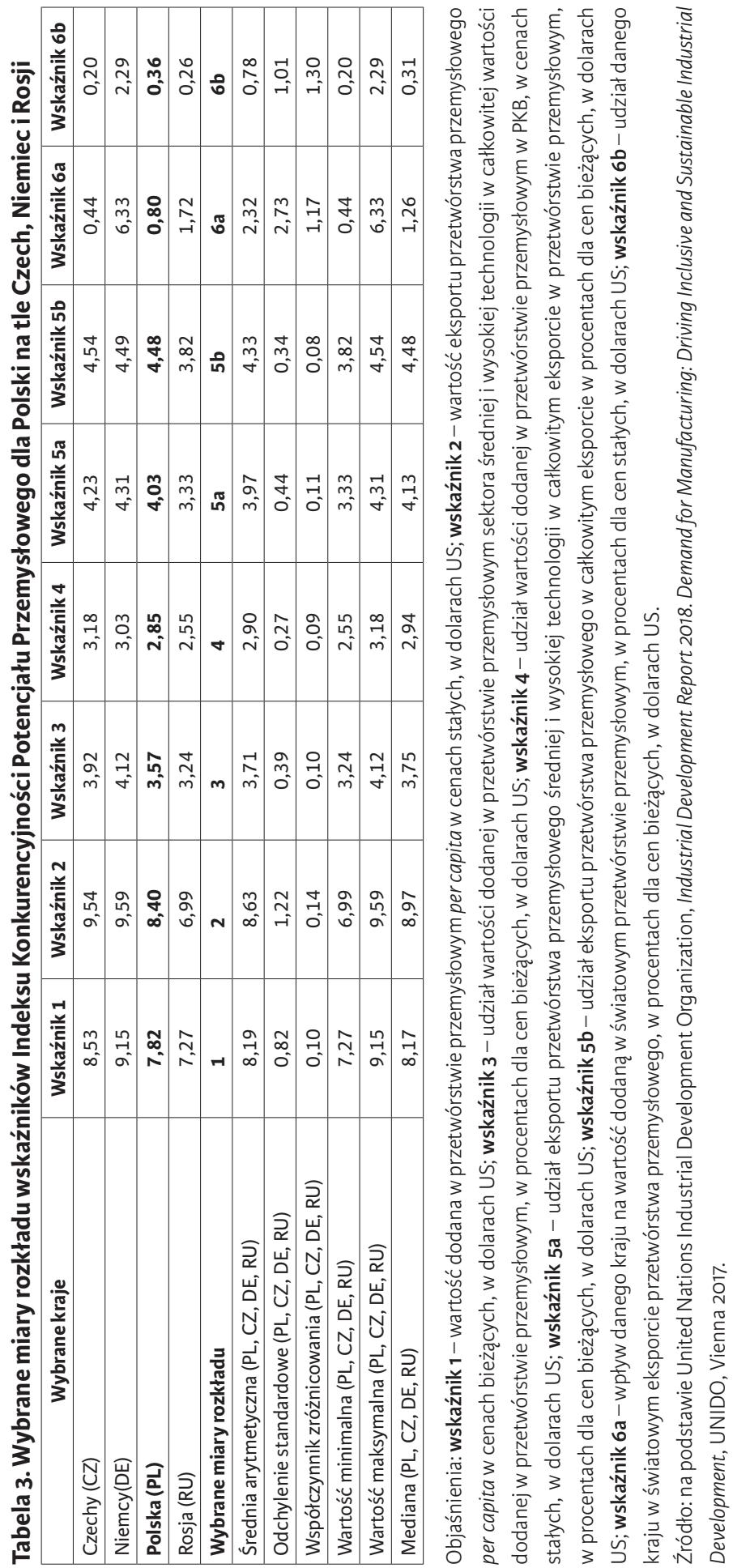




\section{Wykres 5. Wyniki wskaźników Indeksu Konkurencyjności Potencjału Przemysłowego dla Polski na tle Czech, Niemiec i Rosji}

$6 b$

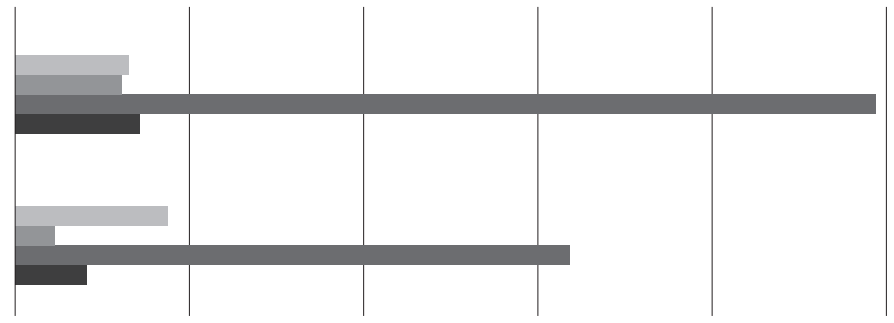

0

2

4

6

8

10

$5 b$

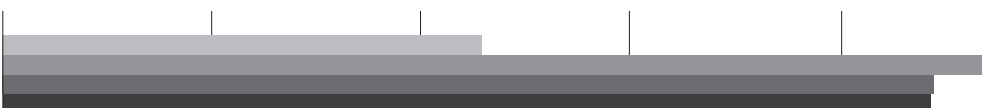

$5 a$
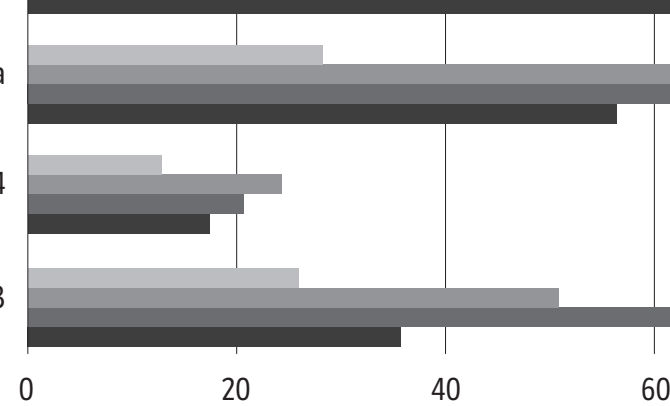

40

60

80

100

2

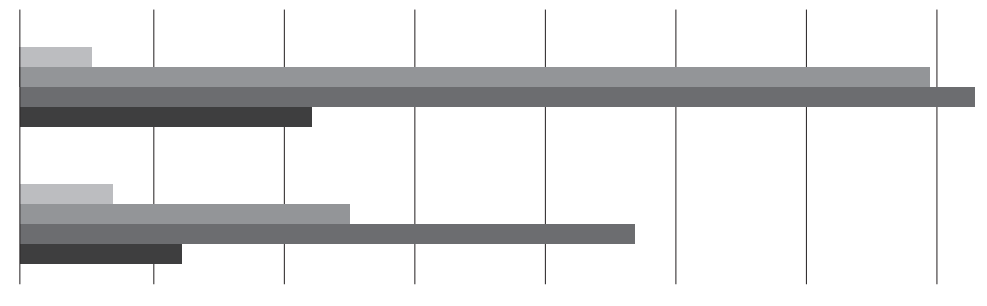

$0 \quad 2000$

4000

6000

8000

10000

12000

14000

16000

Rosja Czechy $\square$ Niemcy Polska

Objaśnienia: wskaźniki na osi X jak w opisie tabeli 3.

Źródło: jak pod tabelą 3.

od Niemiec, ale także znajduje się daleko w stosunku do gospodarki czeskiej (co najmniej dwukrotna różnica). Zarówno wartość dodana w przetwórstwie przemysłowym per capita (wskaźnik nr 1), jak i wartość eksportu per capita (wskaźnik 2) stanowiły w gospodarce polskiej istotną słabość (dane na koniec 2015 r.). Niemniej ważną informacją jest to, że jeżeli już eksportujemy, to w eksporcie przetwórstwo przemysłowe odgrywa niemal tak istotną rolę jak w Niemczech i w Czechach (wskaźnik 5b). Dostrzeżono po raz kolejny istotny problem z inno- 
wacyjnością w Polsce, chociaż w Indeksie Konkurencyjności Potencjału Przemysłowego wyniki są nieco lepsze niż we wcześniej omówionym Globalnym Indeksie Konkurencyjności. Wskaźnik nr 5a, czyli udział eksportu przetwórstwa przemysłowego średniej i wysokiej technologii w całkowitym eksporcie przetwórstwa przemysłowego, jest istotnie niższy w Polsce w porównaniu z Czechami i Niemcami, ale, co pozytywne, znacznie wyższy niż w Rosji. Z kolei wpływ przetwórstwa przemysłowego Polski na gospodarkę światową jest zdecydowanie poniżej potencjału (wymiar trzeci, wskaźniki 6a i 6b). Wskaźnik nr 6b, czyli udział danego kraju w światowym eksporcie przetwórstwa przemysłowego, jest w Polsce na zbliżonym poziomie do Czech, przy czym wielkość gospodarek i populacji różni się istotnie. Niestety wynik ten jest bardzo negatywny i obrazuje wciąż ogromną lukę w rozwoju przetwórstwa przemysłowego w Polsce w stosunku do potencjału.

\section{Podsumowanie}

W niniejszym opracowaniu ukazano wciąż słabą konkurencyjność międzynarodową polskiego przemysłu na tle wybranych państw Europy i świata, przy znacznym i niewykorzystanym potencjale krajowej gospodarki. Powstaje pytanie, czy w doganianiu czołówki państw w zakresie konkurencyjności gospodarki i przemysłu takich krajów, jak: Niemcy, Szwajcaria, Holandia, Finlandia, Japonia, Singapur, Korea Południowa, będziemy pokonywać te wszystkie etapy rozwoju, jak wskazane kraje na przełomie wieków, czy jednak skorzystamy z korzyści globalizacji i szybkiego postępu technologicznego, jaki niesie druga dekada XXI wieku. Wydaje się, że automatyzacja produkcji, a także wykorzystanie robotów przemysłowych powinno być wspierane tworzeniem informatycznych ekosystemów, integrując cały łańcuch wartości od opracowania produktu do jego sprzedaży, od dostawców do konsumentów ${ }^{29}$. Przede wszystkim jednak powinno powstać otoczenie biznesowe wyraźnie sprzyjające tworzeniu zaawansowanych technologicznie produktów.

W opinii autorów niniejszego artykułu jednym z zasadniczych kryteriów oceny instrumentów polityki gospodarczej powinien być charakter ich oddziaływania na produktywność polskich przedsiębiorstw. Dbałość państwa o zwiększanie tej produktywności będzie wzmacniać przewagę konkurencyjną, a jednocześnie będzie stanowić główną siłę długookresowego wzrostu gospodarczego, podnosząc jakość życia mieszkańców. Współcześnie polskie przedsiębiorstwa generują nadwyżki handlowe w wymianie produktów stosunkowo mało zaawansowanych technologicznie. Konkurują one na rynkach światowych przede wszystkim wyraźnie niższymi kosztami pracy, gdyż nie mają jeszcze potencjału, w wymiarze globalnym, do tworzenia przewagi konkurencyjnej dzięki

29 Przemysł 4.0, czyli wyzwania współczesnej produkcji. Raport PwC 2017, https://www. pwc.pl/pl/pdf/przemysl-4-0-raport.pdf [dostęp: 16 czerwca 2018 r.]. 
produktywności. Warto podkreślić, że nagły i spory wzrost kosztów pracy, bez ich zrównoważenia wzrostem produktywności, może doprowadzić do utraty międzynarodowej przewagi konkurencyjnej polskich przedsiębiorstw.

Ocenia się, że wpływ gospodarki Polski na gospodarkę światową jest znacznie poniżej potencjału gospodarczego kraju. Jak wskazano w opracowaniu, sytuacja ta wynika przede wszystkim ze słabej innowacyjności polskich przedsiębiorstw, niskiej jakości otoczenia instytucjonalnego i wyraźnie gorszego potencjału technologicznego. W tym obszarze zwłaszcza Czechy i Niemcy osiągają wyniki wyraźnie lepsze niż Polska. Wydaje się wskazane, aby w polityce gospodarczej znacznie większą uwagę zwrócić na ocenę efektywności i skuteczności rozwiązań państw sąsiadujących z Polską w zakresie poprawy międzynarodowej konkurencyjności przedsiębiorstw.

\section{Bibliografia}

Ajitabh A., Momaya K., Competitiveness of Firms: Review of Theory, Frameworks and Models, „Singapore Management Review” 2004, nr 26(1).

Bayoumi T., Saito M., Turunen J., Measuring Competitiveness: Trade in Goods or Tasks?, IMF Working Paper 13/100, IMF, Washington 2013, http://dx.doi. org/10.5089/9781484325803.001.

Blecker J., The Trade Deficit Trap: How It Got So Big, Why It Persists, and What to Do About It, Working Paper No. 284, Economic Policy Institute, Washington 2009.

Boguszewski P., Mirowska-Wierzbicka D., Globalny raport konkurencyjności 2017-18 Światowego Forum Gospodarczego, Narodowy Bank Polski, Warszawa 2017.

Deardorff A., The General Validity of the Law of International Competitiveness, „Journal of Political Economy" 1980, nr 88(5), https://doi.org/10.1142/9789814340373_0010.

Delgado M., Ketels C., Porter M., Stern S., The Determinants of National Competitiveness, NBER Working Paper 18249, National Bureau of Economic Research, Cambridge 2012, https://doi.org/10.3386/w18249.

Dixit A., Stiglitz J., Monopolistic Competition and Optimum Product Diversity, „American Economic Review” 1977, nr 67(3), https://doi.org/10.1017/cbo9780511492273.005.

Dzikowska M., Gorynia M., Teoretyczne aspekty konkurencyjności przedsiębiorstwa w kierunku koncepcji eklektycznej?, „Gospodarka Narodowa” 2012, nr 4.

Francis A., Tharakan P., The Competitiveness of European Industry, Routledge, London 1989.

Gorynia M., Międzynarodowa konkurencyjność polskiej gospodarki a polityka ekonomiczna, „Ekonomista” 1996, nr 3.

Greenhalgh C., Taylor P., Innovation and Export Values and Prices, „CEPR Discussion Papers" 1990, Nr 487, https://doi.org/10.1093/oxfordjournals.oep.a042115.

Greenhalgh Ch., Taylor P., Wilson R., Innovation and Export Values and Process - a Disaggregated Study, „Oxford Economic Papers” 1994, nr 46(1), https://doi.org/10.1093/ oxfordjournals.oep.a042115. 
Hall R.E., Jones C.I., Why Do Some Countries Produce So Much More Output per Worker than Others?, „Quarterly Journal of Economics” 1999, nr 114(1), https://doi. org/10.3386/w6564.

IADB, The Age of Productivity: Transforming Economies from the Bottom up, Inter-American Development Bank, Washington, April 2010.

Kałowski A., Wysocki J., Zmiany w organizacji współczesnych przedsiębiorstw , „ZS WSH Zarządzanie" 2014, nr 1.

Kaźmierski J., Klastry jako źródło efektów synergetycznych i instrument zarządzania regionalnego, „Acta Universitatis Lodziensis. Folia Oeconomica” 2011, nr 251.

Krugman P., Competitiveness: A Dangerous Obsession, „Foreign Affairs” 1994, nr 73(2), https://doi.org/10.2307/20045917.

Krugman P., The Age of Diminished Expectations, The MIT Press, Cambridge 1990, https://doi.org/10.2307/2555071.

Lanz R., Miroudot s., Nordås H.K., Trade in Tasks, „OECD Trade Policy Working Papers” 2011, nr 117.

Lenz A.J., Beyond Blue Economic Horizons: U. Trade Performance and International Competitiveness in the 1990s, Praeger, New York 1991.

Lewney R., Study on the Cost Competitiveness of European Industry in the Globalization Era. Empirical Evidence on the basis of Relative Unit Labour Cost at Sectoral Level, Ecorys 2011.

Luka konkurencyjna na poziomie przedsiębiorstwa a przystapienie Polski do Unii Europejskiej, red. M. Gorynia, Wydawnictwo Akademii Ekonomicznej w Poznaniu, Poznań 2002.

Malaga K., O niektórych dylematach teorii wzrostu gospodarczego i ekonomii, 2012, http:// www.pte.pl/pliki/2/12/K.\%20Malaga.pdf.

O strategii, Harvard Business Review Polska, ICAN Sp. z o.o., Warszawa 2012.

Olczyk M., Kordalska A., Identyfikacja konkurencyjności sektorów przemysłu przetwórczego i ich wptyw na międzynarodową konkurencyjność gospodarki polskiej - analiza panelowa w modelu ECM, seria „Materiały i Studia. Narodowy Bank Polski”, nr 311, Warszawa 2015.

Parry R., U.S Trade Deficit and International Competitiveness, „Business Economics” 1994, nr 29(1).

Porter M., Stern S., Green M., Social Progress Index 2015, Social Progress Imperative, London, 2015.

Porter M., The Competitive Advantage of Nations, Macmillan Press, 1990.

Przemyst 4.0, czyli wyzwania współczesnej produkcji. Raport PwC 2017, https://www. pwc.pl/pl/pdf/przemysl-4-0-raport.pdf.

Siudek T., Zawojska A., Competitiveness in The Economic Concepts, Theories And Empirical Research, „Oeconomia” 2014, nr 13(1).

Soete L., A General Test of Technological Gap Trade Theory, „Weltwirtschaftiches Archiv” 1981, nr 117(4). 
Strategia i planowanie biznesu, red. P. Lis, Wydawnictwo Uniwersytetu Ekonomicznego w Poznaniu, Poznań 2014.

The Global Competitiveness Report 2017-2018, red. K. Schwab, World Economic Forum, Geneva 2017.

Turner A.G., Golub S.S., Towards a System of Unit Labor Cost-Based Competitiveness Indicators for Advanced, Developing and Transition Countries, Staff Studies for the World Economic Outlook, IMF Working Paper 97/151, (1997), https://doi. org/10.5089/9781451922882.001.

Turner P., Van't Dack's J., Measuring International Price and Cost Competitiveness, BIS Economic Paper, 39, Basle 1993.

United Nations Industrial Development Organization, Industrial Development Report 2018. Demand for Manufacturing: Driving Inclusive and Sustainable Industrial Development, Vienna 2017, https://doi.org/10.18356/62a26775-en.

Van Ark B., Stuiwenwol E., Ympa G., Unit Labour Costs, Productivity and International Competitiveness, Groningen Growth and Development Centre, 2005.

World Economic Forum, The Global Competitiveness Report 2017-2018. Executive Opinion Survey, Geneva 2017.

Wziątek-Kubiak A., Konkurencyjność polskiego przemysłu, Bellona, Warszawa 2003. 